\title{
Characteristics of Physical and Chemical Properties of Soil in Different Reclamation Years of Opencast Coal Mine Dump in Grassland
}

\author{
Guowang Wang ${ }^{1}$, Jiancheng Yan ${ }^{2,3,}{ }^{*}$, Junhai Gao ${ }^{2}$ and Changshun Wang 4 \\ ${ }^{1}$ Shenhua Baori Hiller Energy Co., Ltd.,Hulunbuir 021500,China; \\ ${ }^{2}$ Tangshan Branch, China Coal Science and Technology Ecological Environment Technology Co, Ltd. ,Tangshan 063012,China \\ ${ }^{3}$ Tiandi(Tangshan) Mining Science and Technology Company Ltd.,Tangshan 063000,China; \\ ${ }^{4}$ Hulunbuir University, Hulunbuir 021000, China.
}

\begin{abstract}
Taking the reclamation waste dump of the open-pit mining area in the east of Inner Mongolia Steppe as our study area, we sampled field investigation and laboratory measurements to study the changes of soil physical and chemical properties in the waste dump of the open-pit mining area during its recovery years. The objective of this study was aiming to provide theoretical support for the ecosystem restoration and reconstruction in the open-pit mining area of grasslands in the Northwest of China. The results showed that: 1) the mechanical composition of soil all layers in different reclamation years was mainly composed of silt, except for $20-30 \mathrm{~cm}$; the silt content was significantly higher than the control area (CK), and the silt content of surface soil $(0-5 \mathrm{~cm})$ in reclamation 3 years (2016) was significantly higher than CK, but the sand content was significantly lower than $\mathrm{CK} ; 2$ ) In the early stage of vegetation restoration and succession, the physical and chemical properties of soil in different reclamation years were significantly different. With the increase of reclamation years, TOC and TN content decreased, but TP content did not change significantly during reclamation years. Based on the above results, the change characteristics of soil physical and chemical properties in the early stage of vegetation restoration succession were discussed. The research results have certain theoretical significance and practical guidance value for the ecological restoration and reconstruction of open-pit mining areas in the north of Northwest China.
\end{abstract}

\section{Introduction}

Open pit mining makes the mining area become a fragile ecosystem with strong erosion, which seriously threatens the sustainable development of the mining area. The waste dump of open pit mine is a special deposit of rock and soil mixed dump, which not only occupies a lot of land, but also has a great impact on the surrounding ecological environment. Moreover, the quality of reconstructed soil is poor, and it is not easy to be reclaimed. Therefore, the reclamation of waste dump has always been an important content of Open-pit Mine Reclamation [1,2]. The domestic research on the reclamation of waste dump began in the 1980s. Since then, the research has been further accelerated. The suitability evaluation and economic benefit analysis of land reclamation of waste dump have been carried out, [3,4]. After the 1990s, the reclamation of open-pit mine waste dump began to move towards practical research. Scholars focused on Antaibao [8-10], Anjialing [11] and other open-pit mine dumps with long mining time. The research on land reclamation of open-pit mine waste dump in grassland area was carried out late [12], but it made rapid progress. Scholars focused on Soil and water conservation [13], soil quality change [1,
14-16] and other directions.

Soil reconstruction is an effective way to solve the problem of insufficient surface soil resources of disturbed soil in mine engineering. The results of soil reconstruction will ultimately affect the restoration of ecosystem and biodiversity in mining area. The study on the change of soil quality after soil reconstruction with different reclamation years will provide theoretical support for the restoration and reconstruction of grassland and even the whole open pit mining area in Northwest China.

\section{Study Area}

Shenhua Baorixile open-pit coal mine is located in Baorixile Town, Chenbalhu Canner, Hulunbuir City, in the east of Inner Mongolia grassland area. The geographical coordinates are between E119 $15^{\prime}$ and $119^{\circ} 36^{\prime}$, N49 ${ }^{\circ} 14^{\prime}-$ $49^{\circ} 30^{\prime}$, and the altitude is $667 \mathrm{~m}-684 \mathrm{~m}$. It is a semi-arid continental climate in the middle temperate zone, with an average annual temperature of $-2.4{ }^{\circ} \mathrm{C}$, an average annual precipitation of $350 \mathrm{~mm}$, an average annual evaporation of $1247 \mathrm{~mm}$, and an average annual wind speed of $3.5 \mathrm{~m} / \mathrm{s}$.

The natural grassland type in the study area is Leymus chinensis + Stipa baikalensis steppe. The main plants are

*Corresponding author: jc_yan@163.com 
Leymus chinensis, Stipa baicalensis, pocokia ruthenica, Cleistogenes squarrosa, etc. The zonal soil type is dark chestnut soil. In 2015 , the traditional $33^{\circ}$ slope was further cut to $14 \sim 16^{\circ}$ and the reclaimed plant was Elymus dahuricus with a sowing rate of $40 \mathrm{~g}$ per $\mathrm{m}^{2}$.

\section{Research Methods}

\subsection{Sample Collection and Oreparation}

In July 2019, the reconstruction and reclamation time of different parts of the dump (2016, 2017 and 2018) was determined by consulting relevant records and visiting the staff of mine greening section. After comprehensively considering the similarity of slope, aspect and irrigation conditions, the south slope of North dump was selected as the research object, and the natural grassland without grazing around the study area was taken as the control (CK).

The depth of each sample is $30 \mathrm{~cm} \sim 10 \mathrm{~cm}$, and the soil is sampled at a depth of $20 \mathrm{~cm}$, and the soil is sampled at a depth of $5 \mathrm{~cm}$. We taked all samples back to the laboratory to dry, grind and sift through $2 \mathrm{~mm}$ sieve for use.

\subsection{Soil Sample Analysis}

Ls13320mw laser particle size analyzer (Beckman Coulter) diffraction analyzer was used to determine the mechanical composition of soil [17]. The soil texture classification system [18] was used to determine the clay particle size of $0-0.002 \mathrm{~mm}$, the powder particle size of $0.002-0.05 \mathrm{~mm}$, and the sand particle size of 0.05-2 $\mathrm{mm}$. Organic matter (TOC) was determined by potassium dichromate sulfate oxidation capacity method; total nitrogen (TN) was determined by potassium sulfate copper sulfate selenium powder digestion and determined by nitrogen analyzer automatic analysis method; total phosphorus (TP) was determined by sulfuric acid perchloric acid digestion and molybdenum antimony resistance colorimetry. The above analysis methods are shown in soil agrochemical analysis method [19].

\subsection{Aata Processing and Analysis}

WPS software was used for drawing, SPSS16.0 software was used for multiple comparison (Turkey test), and the confidence interval was $95 \%$.

\section{Results and Analysis}

\subsection{Effect of Different Reclamation Years on Soil Mechanical Composition of Waste Dump}

Soil mechanical composition is one of the most basic data for studying soil. The temporal variability of soil mechanical composition can be used to evaluate the degree of soil erosion. The difference of soil composition in $30 \mathrm{~cm}$ depth is shown in the table. It can be seen from Table 1 that the soil mechanical composition of each soil layer in different reclamation years is mainly composed of silt, which is more than $60 \%$, and the content of soil clay is the least, less than $10 \%$; the proportion of the three is roughly sand: silt: Clay $=6: 72: 22$. However, CK's sand: Powder: Clay $=8: 65: 26$.

From the perspective of soil sand content, the sand content of $0 \sim 5 \mathrm{~cm}$ soil increased with the increase of reclamation years, and the sand content of $5 \sim 10 \mathrm{~cm}, 10 \sim$ $20 \mathrm{~cm}$ and $20 \sim 30 \mathrm{~cm}$ soil decreased with the increase of reclamation years. Except that the difference of $10 \sim 20 \mathrm{~cm}$ reclamation for 3 years and reclamation for 2 years was not significant, the sand content of other layers had significant difference. Compared with $\mathrm{CK}$, there were significant differences, but no obvious regularity. From the perspective of soil silt content, the silt content of $0 \sim$ $5 \mathrm{~cm}$ soil decreased with the increase of reclamation years, and the silt content of the other three layers increased with the increase of reclamation years. Except for $5 \sim 10 \mathrm{~cm}$, there was no significant difference among other layers. Compared with $\mathrm{CK}$, there were significant differences except $20-30 \mathrm{~cm}$. From the perspective of soil clay content, the clay content of $0 \sim 5 \mathrm{~cm}$ soil decreased with the increase of reclamation years, and the clay content of the other three layers increased with the increase of reclamation years, but there was no significant difference. The content of clay in $0 \sim 5 \mathrm{~cm}$ soil was significantly lower than that in $\mathrm{CK}$, except that there was no significant difference between $0 \sim 5 \mathrm{~cm}$ soil clay and CK.

The silt content of $0 \sim 5 \mathrm{~cm}$ soil was significantly higher than that of the control, the content of sand was significantly lower than that of the control, and there was no significant difference between the soil clay content and the control, indicating that soil and water loss would still occur in the surface soil after 3 years of reclamation.

Table1. Particle size distribution of soil in different reclamation years

\begin{tabular}{|c|c|c|c|c|}
\hline layer & year & Sand $(\%)$ & Silt (\%) & Clay $(\%)$ \\
\hline \multirow{4}{*}{$0 \sim 5 \mathrm{~cm}$} & 2016 & $20.92 \pm 0.03 a$ & $73.13 \pm 0.22 \mathrm{a}$ & $5.95 \pm 0.23 \mathrm{a}$ \\
\hline & 2017 & $21.73 \pm 0.19 b$ & $72.42 \pm 0.4 \mathrm{a}$ & $5.85 \pm 0.4 \mathrm{a}$ \\
\hline & 2018 & $22.36 \pm 0.16 \mathrm{c}$ & $71.87 \pm 0.4 \mathrm{a}$ & $5.78 \pm 0.31 \mathrm{a}$ \\
\hline & $\mathrm{CK}$ & $44.08 \pm 0.27 \mathrm{~d}$ & $50.56 \pm 0.16 \mathrm{c}$ & $5.36 \pm 0.12 \mathrm{a}$ \\
\hline \multirow{4}{*}{$5 \sim 10 \mathrm{~cm}$} & 2016 & $24.61 \pm 0.32 \mathrm{a}$ & $70.08 \pm 0.36 \mathrm{a}$ & $5.31 \pm 0.55 \mathrm{a}$ \\
\hline & 2017 & $22.36 \pm 0.19 \mathrm{~b}$ & $71.74 \pm 0.31 \mathrm{~b}$ & $5.90 \pm 0.54 \mathrm{a}$ \\
\hline & 2018 & $14.23 \pm 0.27 \mathrm{c}$ & $79.63 \pm 0.4 \mathrm{c}$ & $6.13 \pm 0.57 \mathrm{a}$ \\
\hline & $\mathrm{CK}$ & $16.98 \pm 0.34 \mathrm{~d}$ & $74.71 \pm 0.24 \mathrm{~d}$ & $8.31 \pm 0.1 \mathrm{~b}$ \\
\hline \multirow{4}{*}{$10 \sim 20 \mathrm{~cm}$} & 2016 & $24.78 \pm 0.07 \mathrm{a}$ & $70.8 \pm 0.49 \mathrm{a}$ & $4.42 \pm 0.6 \mathrm{a}$ \\
\hline & 2017 & $24.07 \pm 0.11 \mathrm{a}$ & $71.45 \pm 0.6 \mathrm{a}$ & $4.48 \pm 0.66 \mathrm{a}$ \\
\hline & 2018 & $12.75 \pm 0.30 \mathrm{~b}$ & $80.77 \pm 0.09 \mathrm{~b}$ & $6.48 \pm 0.34 \mathrm{a}$ \\
\hline & $\mathrm{CK}$ & $22.91 \pm 0.21 \mathrm{c}$ & $68.06 \pm 0.39 \mathrm{c}$ & $9.02 \pm 0.23 b$ \\
\hline \multirow{4}{*}{$20 \sim 30 \mathrm{~cm}$} & 2016 & $27.37 \pm 0.19 \mathrm{a}$ & $68.51 \pm 0.61 \mathrm{a}$ & $4.12 \pm 0.89 \mathrm{a}$ \\
\hline & 2017 & $24.03 \pm 0.32 \mathrm{~b}$ & $70.97 \pm 0.57 \mathrm{a}$ & $5.00 \pm 0.36 \mathrm{ab}$ \\
\hline & 2018 & $20.28 \pm 0.31 \mathrm{c}$ & $72.61 \pm 0.77 \mathrm{a}$ & $7.11 \pm 0.79 b$ \\
\hline & $\mathrm{CK}$ & $21.45 \pm 0.36 \mathrm{c}$ & $68.47 \pm 0.18 \mathrm{a}$ & $10.08 \pm 0.2 \mathrm{c}$ \\
\hline
\end{tabular}

Note: Different small letters in the same column indicate significant difference among different years in the same soil layer $(\mathrm{P}<0.05)$. The same below.

\subsection{Relationship Between Species Siversity and Soil Chemical Properties}

\subsubsection{Characteristics of Soil TOC Content}

It can be seen from table 2 that the TOC content in $0-5 \mathrm{~cm}$, $5-10 \mathrm{~cm}$ and $10-20 \mathrm{~cm}$ soil layers decreases with the 
increase of reclamation years, and there is a significant difference between them; however, there is no obvious rule of organic carbon content in $20-30 \mathrm{~cm}$ soil layer. The content of soil organic carbon in $0 \sim 5 \mathrm{~cm}, 5 \sim 10 \mathrm{~cm}$ and $10 \sim 20 \mathrm{~cm}$ in three years and two years of reclamation were significantly lower than that of the control, but the difference was not significant between one year reclamation and the control, but it was also slightly lower than the control.

Table2. Total organic carbon content of soil in different reclamation years

\begin{tabular}{ccccc}
\hline layer $(\mathrm{cm})$ & 2016 & 2017 & 2018 & CK \\
\hline $0 \sim 5$ & $21.26 \pm 0.4 \mathrm{a}$ & $23.97 \pm 0.49 \mathrm{~b}$ & $26.17 \pm 0.57 \mathrm{c}$ & $27.31 \pm 0.4 \mathrm{c}$ \\
$5 \sim 10$ & $16.93 \pm 1.19 \mathrm{a}$ & $21.49 \pm 0.47 \mathrm{~b}$ & $31.43 \pm 0.98 \mathrm{c}$ & $31.52 \pm 1.19 \mathrm{c}$ \\
$10 \sim 20$ & $16.69 \pm 1.73 \mathrm{a}$ & $23.88 \pm 1.29 \mathrm{~b}$ & $30.31 \pm 0.22 \mathrm{c}$ & $24.98 \pm 1.73 \mathrm{bc}$ \\
$20 \sim 30$ & $18.78 \pm 1.45 \mathrm{a}$ & $22.52 \pm 0.75 \mathrm{a}$ & $21.69 \pm 0.3 \mathrm{a}$ & $21.5 \pm 1.45 \mathrm{a}$ \\
Average & $18.42 \pm 1.19 \mathrm{a}$ & $22.97 \pm 0.75 \mathrm{~b}$ & $27.4 \pm 0.52 \mathrm{c}$ & $25.9 \pm 1.19 \mathrm{c}$ \\
\hline
\end{tabular}

\subsubsection{Characteristics of Soil TN Content}

With the increase of reclamation years, the content of TN in $0-5 \mathrm{~cm}, 5-10 \mathrm{~cm}$ and $10-20 \mathrm{~cm}$ soil layers decreased significantly, while the content of total nitrogen in 20$30 \mathrm{~cm}$ soil layer did not change significantly. Compared with $\mathrm{CK}$, the content of TN in $0 \sim 5 \mathrm{~cm}$ soil layer was lower than that of $\mathrm{CK}$, but the difference was not significant; the TN content of $5 \sim 10 \mathrm{~cm}$ and $10 \sim 20 \mathrm{~cm}$ soil was significantly lower than that of CK; the TN content of 20 $\sim 30 \mathrm{~cm}$ soil layer was slightly higher than that of $\mathrm{CK}$, but the difference was not significant.

Table3. Total nitrogen content of soil in in different reclamation years

\begin{tabular}{ccccc}
\hline $\begin{array}{c}\text { layer } \\
(\mathrm{cm})\end{array}$ & 2016 & 2017 & 2018 & $\mathrm{CK}$ \\
\hline $0 \sim 5$ & $1.693 \pm 0.033 \mathrm{a}$ & $1.757 \pm 0.024 \mathrm{a}$ & $1.767 \pm 0.08 \mathrm{a}$ & $1.897 \pm 0.118 \mathrm{a}$ \\
& & & & \\
$5 \sim 0$ & $1.387 \pm 0.055 \mathrm{a}$ & $1.687 \pm 0.081 \mathrm{~b}$ & $1.843 \pm 0.019 \mathrm{c}$ & $2.417 \pm 0.147 \mathrm{~d}$ \\
$10 \sim 20$ & $1.497 \pm 0.069 \mathrm{a}$ & $1.64 \pm 0.029 \mathrm{~b}$ & $1.70 \pm 0.049 \mathrm{c}$ & $2.033 \pm 0.192 \mathrm{~d}$ \\
$20 \sim 30$ & $1.617 \pm 0.07 \mathrm{a}$ & $1.96 \pm 0.057 \mathrm{a}$ & $1.907 \pm 0.084 \mathrm{a}$ & $1.583 \pm 0.2 \mathrm{a}$ \\
Average & $1.55 \pm 0.06$ & $1.79 \pm 0.05$ & $1.8 \pm 0.06$ & $1.98 \pm 0.16$ \\
\hline
\end{tabular}

\subsubsection{Characteristics of Coil TP Content}

The content of TP in soil layers increased with the increase of reclamation years, but the difference was not significant. Compared with the control, the content of TP in each layer of soil was higher than that of the control, but the difference was not significant.

Table4. Total phosphorous content of soil in in different reclamation years

\begin{tabular}{ccccc}
\hline layer & 2016 & 2017 & 2018 & CK \\
\hline $0 \sim 5 \mathrm{~cm}$ & $0.403 \pm 0.024 \mathrm{a}$ & $0.367 \pm 0.022 \mathrm{a}$ & $0.343 \pm 0.014 \mathrm{a}$ & $0.350 \pm 0.012 \mathrm{a}$ \\
$5 \sim 10 \mathrm{~cm}$ & $0.378 \pm 0.021 \mathrm{a}$ & $0.367 \pm 0.009 \mathrm{a}$ & $0.356 \pm 0.02 \mathrm{a}$ & $0.363 \pm 0.044 \mathrm{a}$ \\
$10 \sim 20 \mathrm{~cm}$ & $0.346 \pm 0.017 \mathrm{a}$ & $0.346 \pm 0.008 \mathrm{a}$ & $0.357 \pm 0.017 \mathrm{a}$ & $0.317 \pm 0.045 \mathrm{a}$ \\
$20 \sim 30 \mathrm{~cm}$ & $0.389 \pm 0.029 \mathrm{a}$ & $0.390 \pm 0.019 \mathrm{a}$ & $0.362 \pm 0.019 \mathrm{a}$ & $0.280 \pm 0.038 \mathrm{a}$ \\
\hline
\end{tabular}

\begin{tabular}{lllll} 
Average & $0.379 \pm 0.023 \mathrm{a}$ & $0.368 \pm 0.015 \mathrm{a}$ & $0.355 \pm 0.018 \mathrm{a}$ & $0.328 \pm 0.035 \mathrm{a}$ \\
\hline
\end{tabular}

\section{Discussion}

Soil mechanical composition is one of the most basic data for soil research, which can reflect the size and quantity of soil mineral particles, affect soil and water conservation and the supply of plant nutrients [20]. The results show that, after enclosure of degraded grassland, with the restoration of vegetation, the clay content in soil significantly increases [21], which is different from the results of this study. With the increase of reclamation years, the content of sand increases, while the content of clay decreases, which is consistent with the research results of Liu Jun on the waste dump of Huolin Henan open-pit coal mine [22], which may be due to the natural restoration of soil Even if the upper layer is covered with the original topsoil, the original sequence of occurrence layer will be destroyed, and eventually the soil properties will be changed.

Organic matter is an important part of soil and plays an important role in soil fertility and environmental protection [23]. The input of soil organic matter mainly comes from the accumulation of surface biomass and the contribution of human activities, while the output is mainly from the decomposition of various life activities and the output with soil and water loss . Generally speaking, soil organic matter content increases with the increase of reclamation years, but this study shows that with the increase of reclamation years, soil organic carbon content decreases. The lowest content of organic matter was found in the soil after 3 years of reclamation, which may be due to the loss of original accumulated nutrients with the loss of soil clay after soil disturbance. At the same time, due to the short recovery time, the vegetation coverage is not as good as the surrounding grassland, and the surface litter remains less, which can't effectively supplement soil nutrients, which is basically consistent with the research results of Su Zhongfei et al. The content of $\mathrm{TN}$ in different reclamation years was consistent with that of TOC, and decreased with the increase of reclamation years.

Most of the phosphorus in soil comes from soil parent material except for a small part from dry wet deposition. In addition to the loss of surface runoff, the phosphorus in soil is almost negligible [23]. Some studies have shown that, in the natural grassland vegetation restoration succession, the soil total $\mathrm{P}$ content also increases with the increase of the restoration year, and has a significant correlation with the restoration year. In this study, although there are similar characteristics, the difference is not significant. It is speculated that the reason is due to the implementation of reclamation project, the original $0 \sim 30$ $\mathrm{cm}$ soil layer is mixed and then covered again.

In this study, the soil quality of three years of reclamation is obviously inferior to the surrounding natural grassland, but the soil quality of one-year reclamation is similar to that of surrounding natural grassland, which is the same as the dynamic evolution law of soil quality of Yimin mining area in Inner Mongolia: "the growth rate of soil quality in the initial stage of 
reclamation is fast, and with the increase of reclamation time, the recovery speed of soil quality is gradually slow, close to the original landform". It has been reported in some studies that after full enclosure of severely degraded grassland, good restoration effect can be achieved about 8-12 years; for waste dump restored by artificial intervention, it is reported that the surface soil quality can reach the level of undisturbed soil after 5 years of Reclamation [14]. It can be seen that the artificial intervention will accelerate the reclamation speed of the waste dump in the mining area, but the specific recovery time of the ecological system structure and function of the dump still needs to strengthen the long-term positioning monitoring.

\section{Acknowledgment}

This paper is supported by National Key R\&D Program of China(2016YFC0501105) and Special Youth Project of Science and Technology Innovation and Entrepreneurship Fund of Tiandi Science and Technology Co., Ltd (2018TD-QN041).

\section{References}

1. J. Wang, Z.Bai, R.Yang . Succession Law and Model of Reclaimed Soil Quality of Opencast Coal Mine Dump in Grassland. Transactions of the Chinese Society of Agricultural Engineering, 28,229235(2012).

2. Z. Hu. The 30 Years Land Reclamation and Ecological Restoration in China: Review, Rthinking and Prospect. Coal Science and Technoloy, 47,2535(2019).

3. HU Zhen-qi. Spatial Variability of Physical Properties of Reclaimed Soil in Surface Coal Mine[J]. Journal of China University of Mining \& Technology, 3440(1992).

4. W. Wang. Preliminary Studies on the Evaluation Method of the Suitability of Land Reclamation in Open Cast Mines. Opencast Mining Technology, 7275(2013).

5. G.Liu, R. Bi, Y. Cao. On the Economic Benefits of Land Reclamation in Open Cast Coal Mine Dump Site .China Coal, 109-111(2008).

6. J. Huang, J.Sun. Present Situation and Assumption of Open Pit Reclamation in Masteel [J]. Metal Mine Design and Construction, 47-50(1994).

7. S. Chai, Z. Bai. Study on Lnad Reclamation-growing and Runoff Characteristic of Surface Rock Soil on Soil-discharged Fields in Antaibao Opencut Coal Mine. Coal Mine Environmental Protection, 22-26 (1999).

8. S. Chai, Z. Bai. Relationship between Surface Runoff Characteristics and Plantation in reclaimed land on dumps of Antaibao open-Pit mine. Metal Mine Design and Construction, 49-53(1995).

9. G. Wang, X.Wang, D. Li, et al. Correlation between Nutrients of Reclaimed Soil in Antaibao Opencast
Mine.Coal Mine Environmental Protection, 25-27 (2001).

10. X. Li, Z. Zhang. Analysis of Land Reclamation in Mine Dump of Fuxin. Journal of Liaoning Technical University(Natural Science),S2,251-253(2009).

11. P. Tai, T. Sun , H.Jia , et al. Restoration for Refuse Dump of Open-Cast Mine in Steppe Region. Journal of Soil and Water Conservation, 90-93 (2002).

12. J. Wei. Discussion of Land Rehabilitation Pattern After Mining in Open Pit Mine . Coal Science and Technoloy,S2,384-385(2013) .

13. H.Sun, X. Li ,Z. Hu, et al. Variance of reclamation soil quality in Majiata opencast mine region., 205209,24(2008).

14. X. LIU, Q. Zhu, Z. Hu, et al. Reclamation Soil Quality Change Characteristics of Open-pit Coal Mine Dump Site Slope in Weakened Ecological Grassland Region .JiangSu Agricultural Sciences,45, 242-244 (2017).

15. S. Wang, Y. Cao, G. Luo, et al. Effects of Reconstructing Soil in Open Cast Mining Areas of the Loess Plateau on Soil Physical Properties and Vegetative Growth. Journal of Agricultural Resources and Environment, 36, 344-354 (2019).

16. J.Wang, R. Yang, Z. Bai. Succession Law and Model of Reclaimed Soil Quality of Opencast Coal Mine Dump in Grassland. Transactions of the Chinese Society of Agricultural Engineering, 28, 229235(2012).

17. Y. Chen, Y. Zhang, Z. Tan, et al. Comparison of Particle-size Results of Sediments Measures by the MS2000 and LS13320Laster Diffraction Particle-size Analyzers. Acta Scientiarum Naturalium Universitatis Sunyatseni,57,48-55(2018).

18. K. Wu, R. Zhao. Soil Texture Classification and Its Application in China. Acta Pedologica Sinica , 56,227-241 (2019).

19. S. Bao. Agrochemical Analysis of Soil. (Agriculture Press ,Beijing,2000).

20. L. Wu, X. Jia, H. Wang. Effects of Maize Growth Durations on Soil Physical and Chemical Characteristics After a Slope Hill to a Terrace Landform.Land Development and Engineering Reaearch, 5,38-42(2020).

21. H. FU, Y. Chen, Z. Zhou, et al. Changes of Vegetation and Soil Environment of Desert Grasslandin the Early Period of Restoration in Alxa, Inner Mongolia. Journal of Desert Research,58-61(2003).

22. J. Liu, X. Dang. Effect of Planting Years of Hippophae rhamnoides on Soil Fertility Quality of Dump Slope in Surface Mine. Journal of Zhejiang Forestry Science and Technology ,37,9-14(2017).

23. C. Huang. Pedology . (China Agriculture Press, Beijing, 2002). 